\title{
The state of the Railways in South Africa during the Anglo-Boer War 1899-1902
}

Maj. B.A. Zurnamer*

The railways in South Africa were badly damaged during the Anglo-Boer War by the armed forces of the two Republics during their retreat and the guerilla campaign which followed.

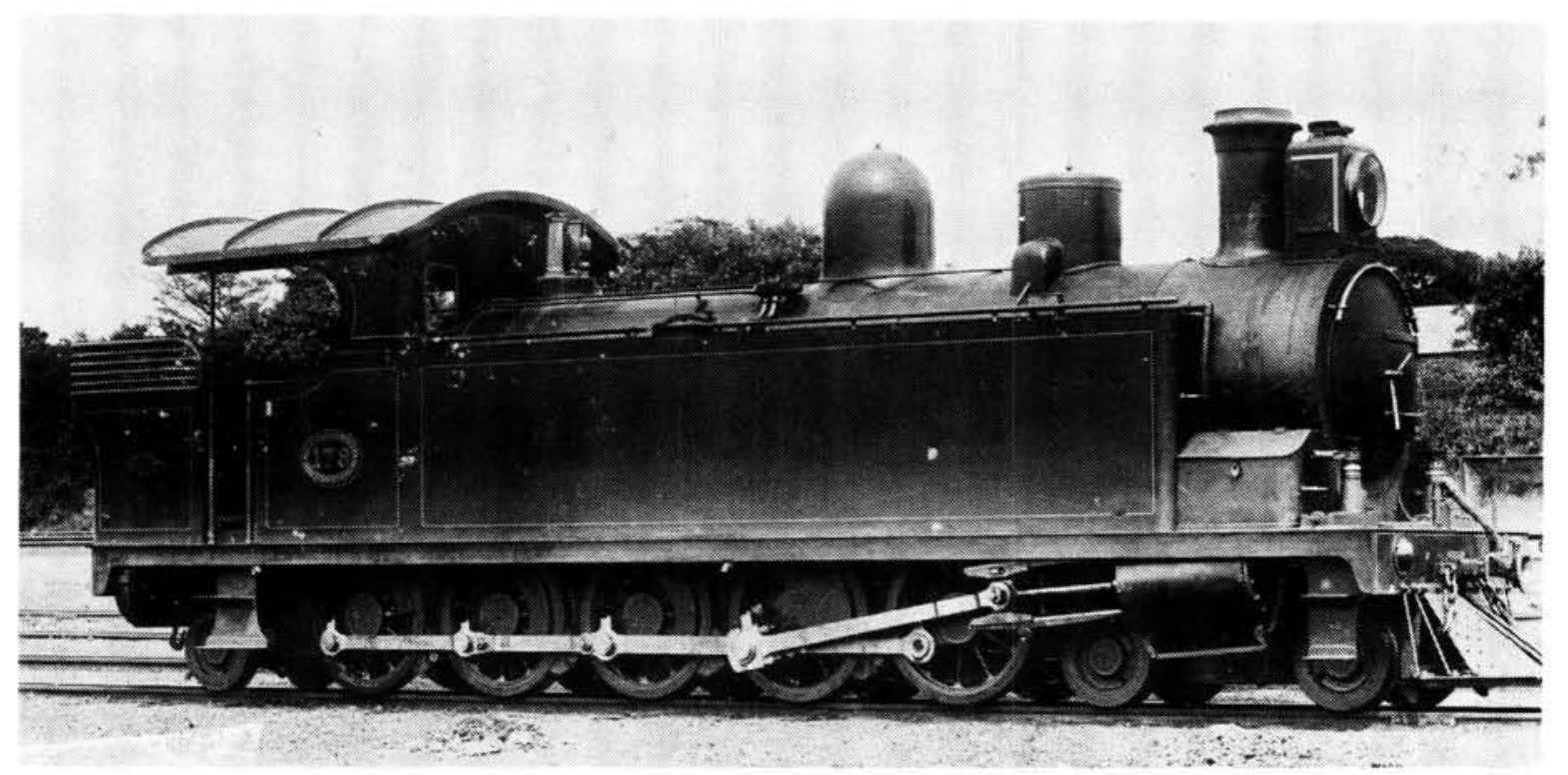

Klas H.2 Lokomotief gebruik gedurende die Anglo-Boereoorlog in Natal

Shortly after the declaration of the War on 11 October 1899, the Republican forces occupied the railways at many key points in Natal and the Cape Colony. In less than six weeks the Boer forces had penetrated deep into enemy territory and were in control of the railway line from Mafeking to a point just north of the Orange River on the Cape Main Line. In Natal the line had been occupied to a point some three miles north of Mooirivier station.

The Republican forces also held the line between Aliwal North and Molteno and the line between Norval's Pont on the Cape-OFS border and as far as Arundel near Noupoort. The important railway bridges at Bethulie on the OFSCape border and at Norval's Pont were also in Boer hands and three strategic railway centres, Mafeking, Kimberley, and Ladysmith were also under siege by the Republican forces.

The railways were considered to be of prime importance by the British as they afforded rapid mobility to their troops who had to be moved from the various ports to the operational areas. Thus, it was essential to establish a military railway organization for the conduct of war in South Africa. So it was that Major E.P.C. Girouard was appointed Director of Railways of the South African Field Force. He was at that time president of the Egyptian State Railways and the situation in South Africa made it imperative for the Imperial Army to transfer him to this country.

The Republican forces were determined to hold the railways where they were in control of them, but when the build-up of enemy forces made this impossible, the Boers' strategy was to destroy the railway installations rather than allowing them to fall into the hands of the British. Thus, the railway bridge over the Orange River at Norval's Pont and the one at Bethulie which also crossed the Orange, were destroyed. The bridges over the Tugela River at Colenso, those over the Vaal at Standerton, Fourteen Streams and Vereeniging were also blown up and destroyed. The bridge over the Modder River, south of Kimberley, was also destroyed. 


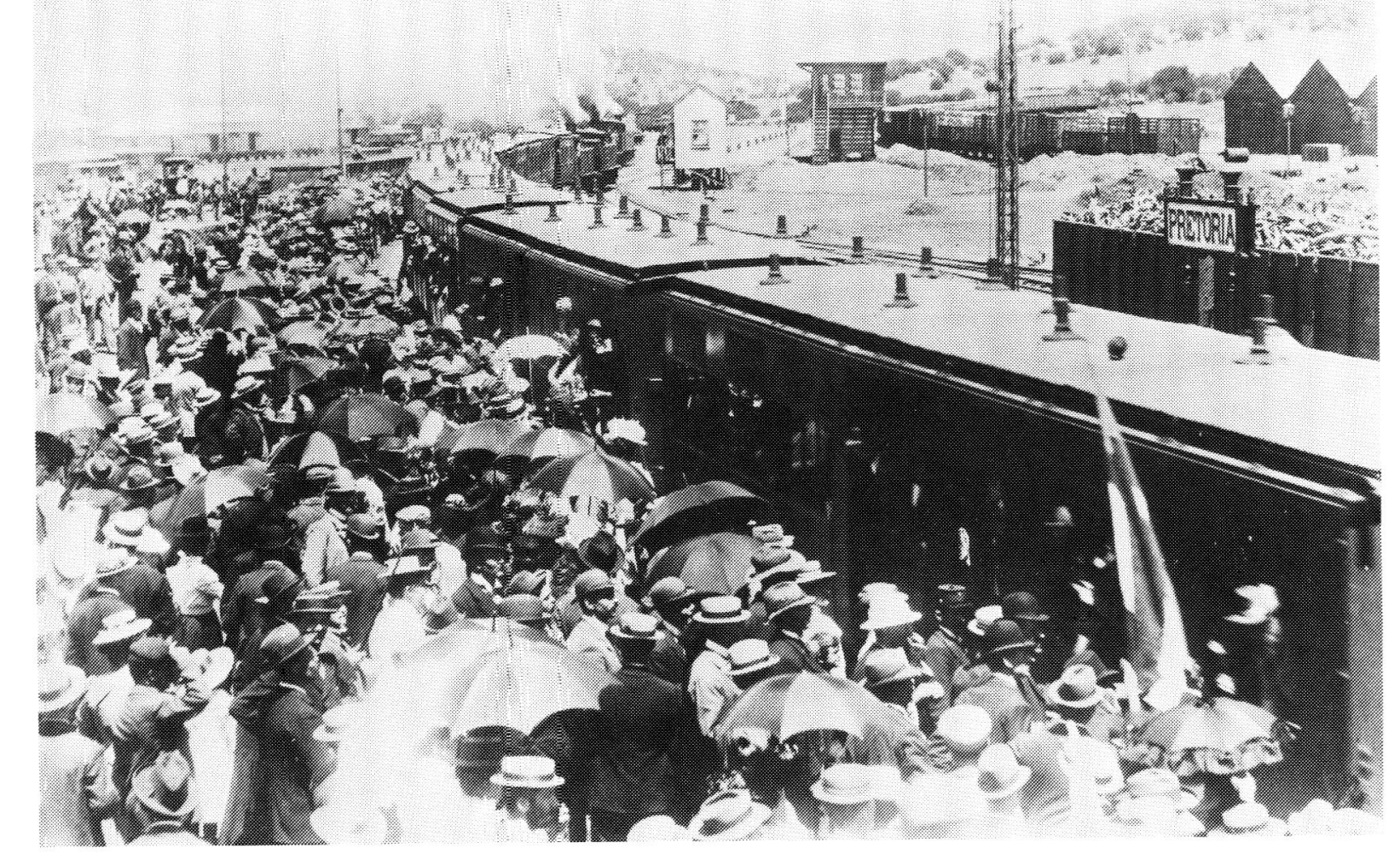

Trein met troepe voor Norvalspont

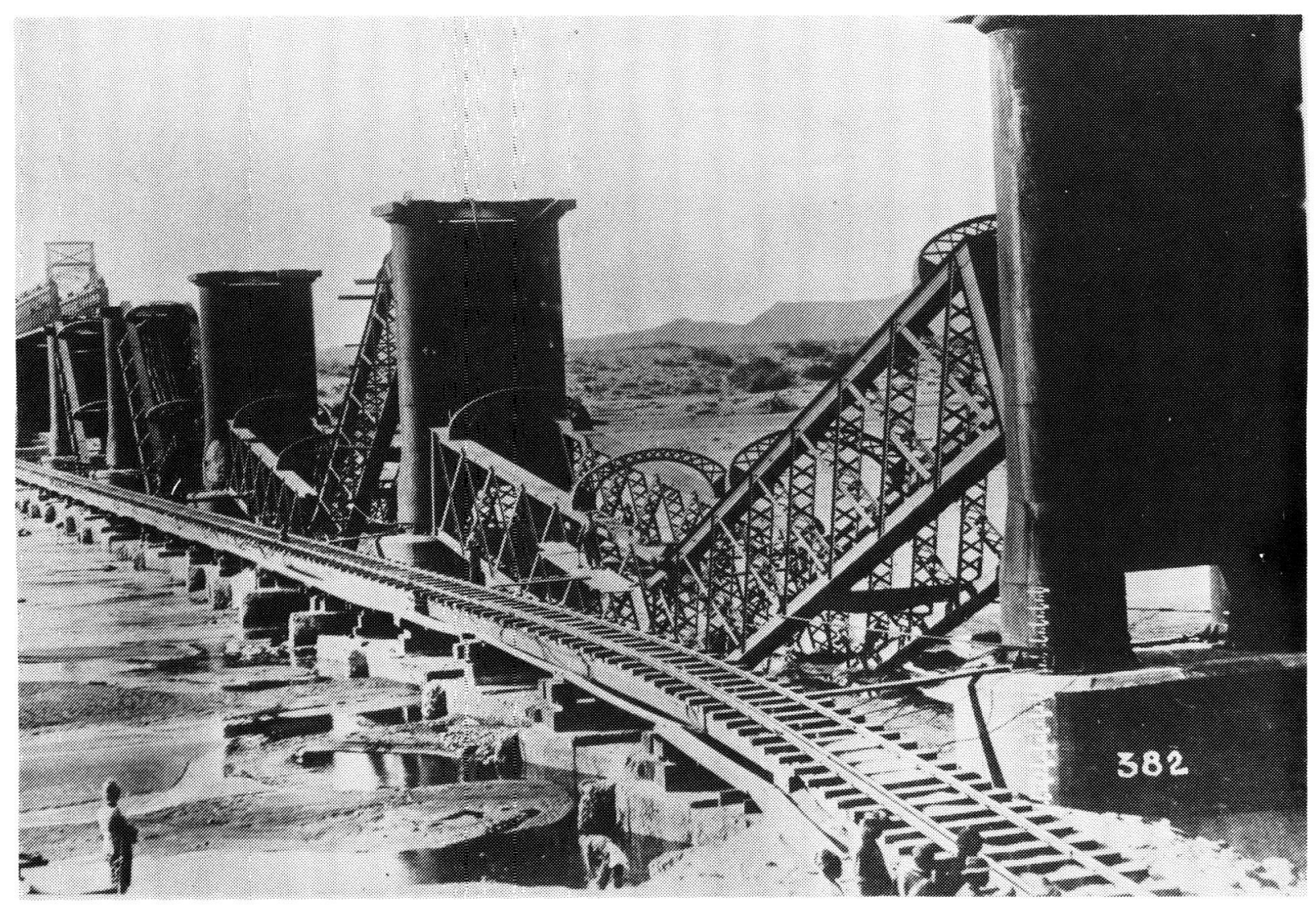

Norvalspont Brug opgeblaas deur die Boere 1900 
Every bridge and culvert from a point north of Bloemfontein was destroyed including those over the Modder, Sand, Vet, Vals, Doring and Renoster Rivers. The bridge at Frere in Natal and eleven other major bridges north of Colenso suffered the same fate.

As if this were not enough, seven important rail- way bridges in the Cape Colony were destroyed, as well as 16 in the Transvaal - nine of them on the Pretoria-Komatipoort main line and the branch line to Barberton. To this must be added 73 smaller bridges and a similar number of culverts over various sections of the railway lines in the war-torn Republics and Colonies.

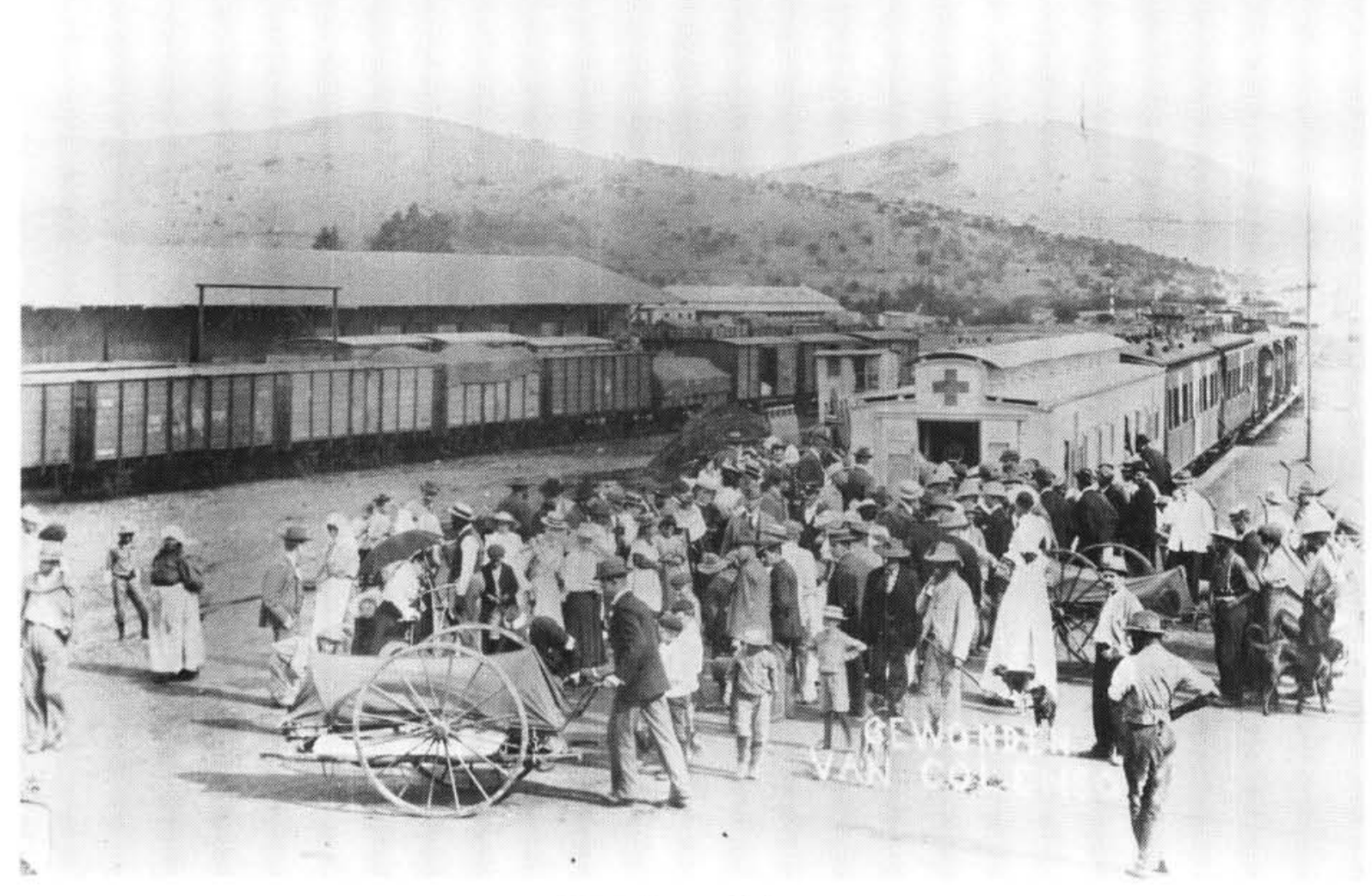

Gewondes van Colenso

The only tunnel to suffer major damage was that at Laingsnek in Natal, but rails, points, crossings and loops were either torn up or blown up in the Republican campaign to thwart the Imperial forces. In some places the railway lines were damaged for several miles. The same fate befell telegraph lines, batteries, water pumps and other installations. Even large boulders were dislodged from hillsides and rolled on to the tracks.

Rolling stock was damaged or completely destroyed and locomotives were rendered inoperable by removing essential parts from them. The Boers also concentrated 222 locomotives and more than 4200 items of other rolling stock on the Pretoria-Komatipoort line and set alight 1000 tons of coal at Komatipoort before destroying the railway station.

Major Girouard was completely taken aback by the destruction inflicted by the Boers and the completeness of their scorched earth policy that he said "the enemy had destroyed the railway in a manner probably unprecedented in any campaign. The damage in the Orange Free State was so numerous that the work of the construction train was unable to keep pace with the Army, in spite of every effort to expedite the work." 


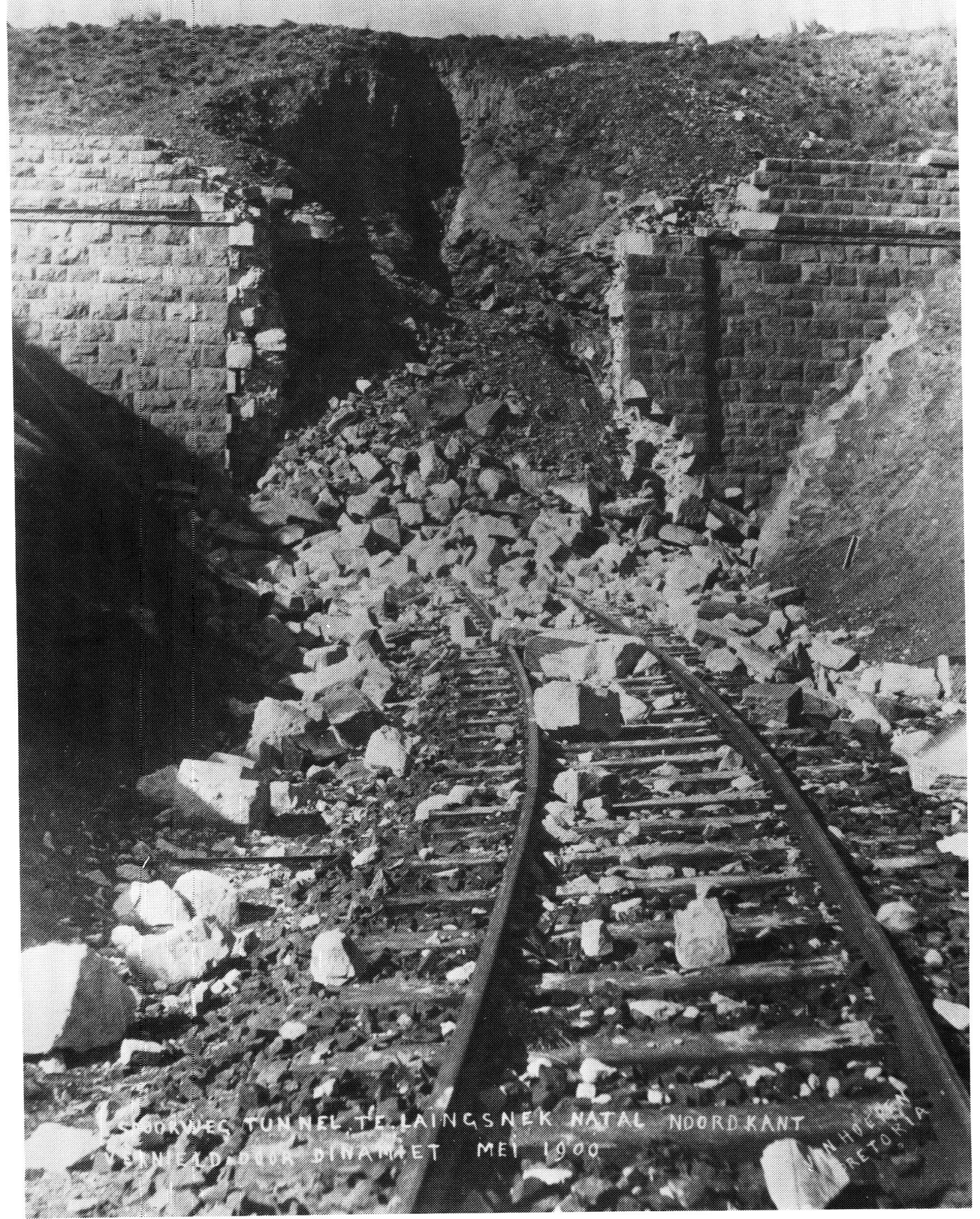

Spoorwegtonnel te Laïngsnek Natal. Noordekant verniel deur dinamiet Mei 1900. 


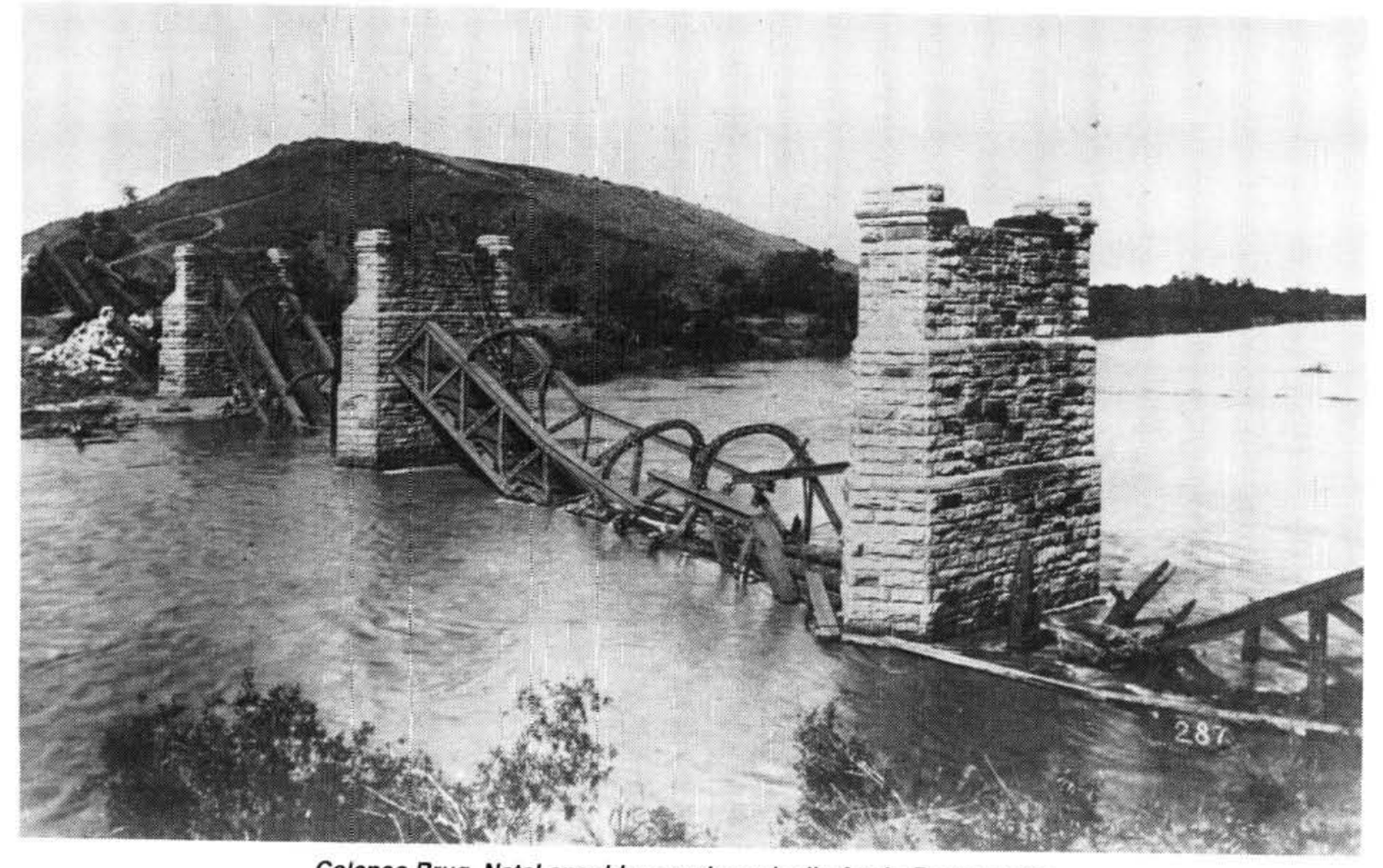

Colenso Brug, Natal opgeblaas gedurende die Anglo-Boereoorlog

The line between Springfontein and Viljoensdrif, after being repaired by the Royal Engineers and the Railway Pioneer Regiment, was continuously damaged by the Boers over a period of 13 months. The Boers also launched frequent attacks on every section of railway line north of Vereeniging as far as Paardekop, Elandshoek, Naboomspruit and west to Klerksdorp. Trains were attacked, captured or derailed and the attacks on railway stations and other installations were led by General C.R. de Wet and General Stoffel Froneman, who aided by the efficient Commandants Danie Theron, Gideon Scheepers, Michal Prinsloo and Steenkamp and Captain Melt van Schoor, inflicted the greatest damage and loss on the British.

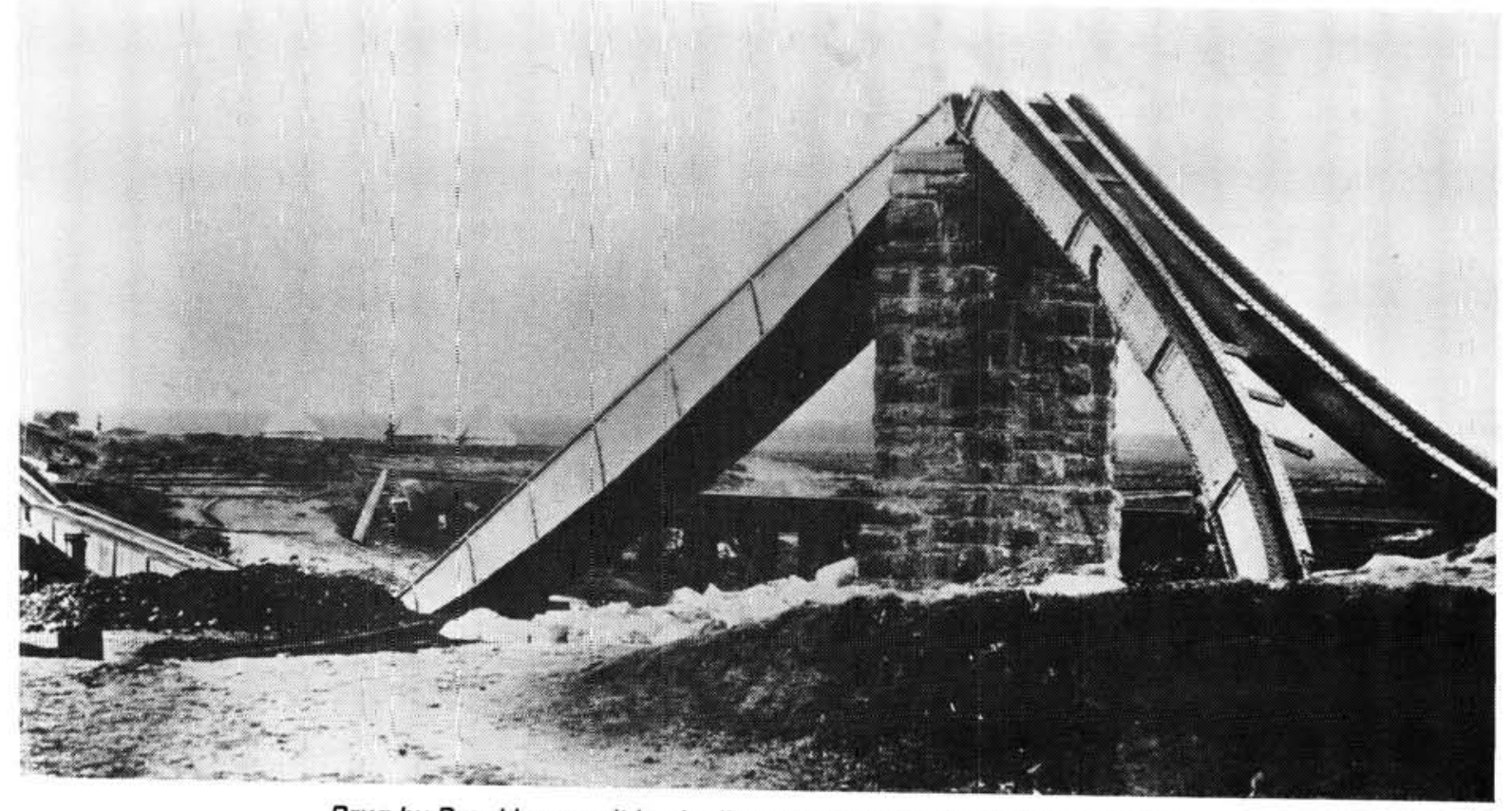

Brug by Bronkhorspruit beskadig gedurende die Anglo-Boereoorlog 
While the above-mentioned military strategists were busy in the Cape and Free State, General Ben Viljoen and General C.H. Muller were conducting similar operations in the Transvaal as were Commandant Trichardt and Captain Slegtkamp.

This strategy of the Boer forces eventually led to. the suspension of rail traffic during night time.
The British also made provision for armoured trains to counter the Boer moves and a six-inch gun was mounted at the back of almost every train. The raids continued however, and the British started erecting blockhouses in 1901. These forts were spaced along the railway lines at an average distance of 2000 yards apart and each was garrisoned by ten men and surrounded by barbed wire.

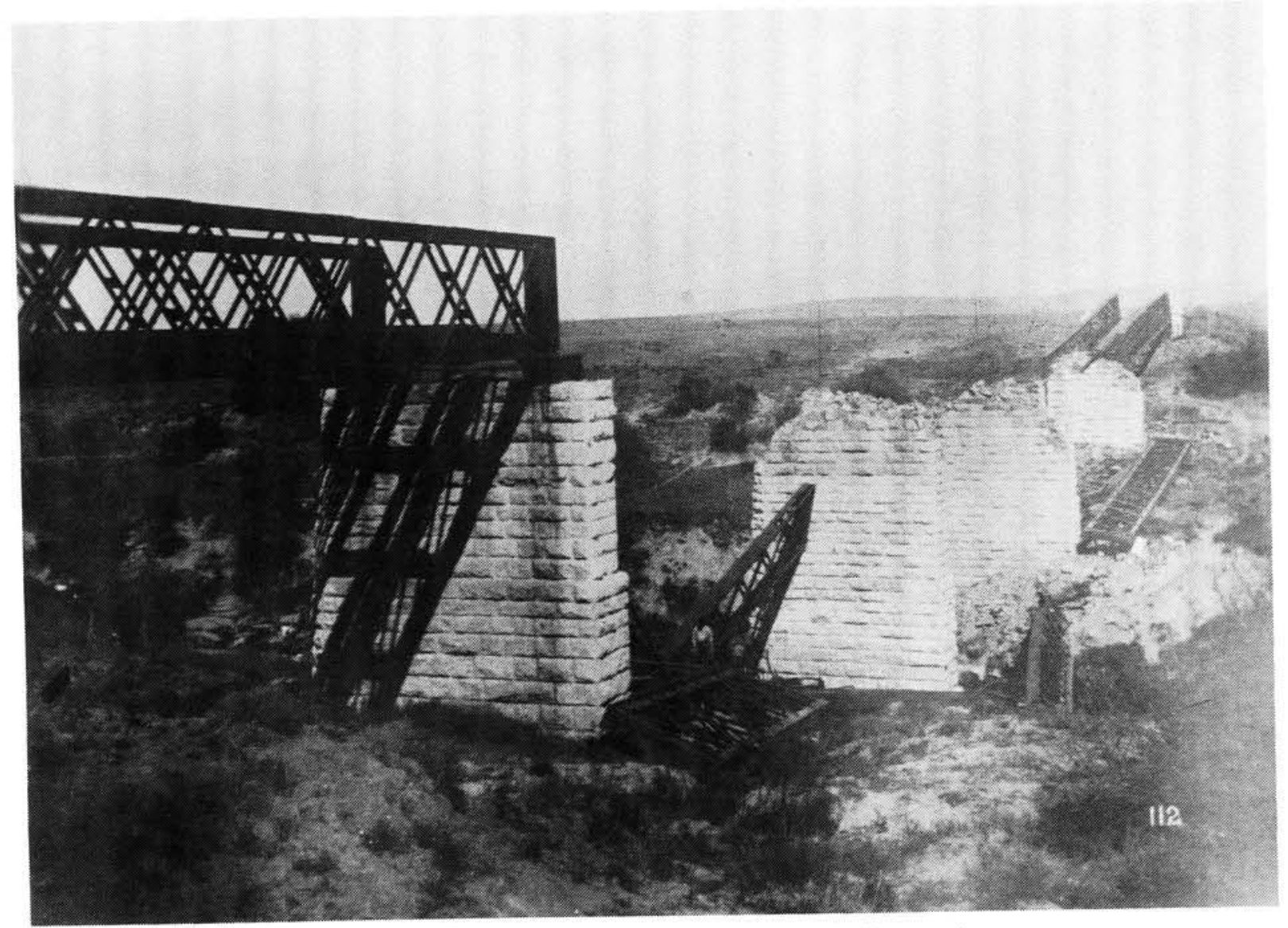

Vetrivier Brug OVS opgeblaas gedurende die Anglo-Boereoorlog

Railway engines were also provided with armour plating and almost every train had two or three trucks coupled to the front of the locomotive to minimize the effects of exploding mines.

When peace was declared on 31 May 1902, the Boers were still hard at attacking railway installations and the British were still trying out various methods of defence.
It is therefore obvious that the cost of restoring rail services in South Africa after the Anglo-Boer War was immense to say the least.

Extract from the book "South Africa's Rail Power" by Bernard Zurnamer - to be published soon.

"Major B.A. Zurnamer is also the author of a series of articles 'The Locomotives of the South African Railways (1971). He has written a number of articles on trains for several magazines. 


\section{Annexure}

The railways were of great strategic importance to the British during the Anglo-Boer War. De Wet and other lesser Boer generals realised this and with the aid of small guerilla parties, sometimes consisting only of two men, caused untold damage to the British lines of communication.
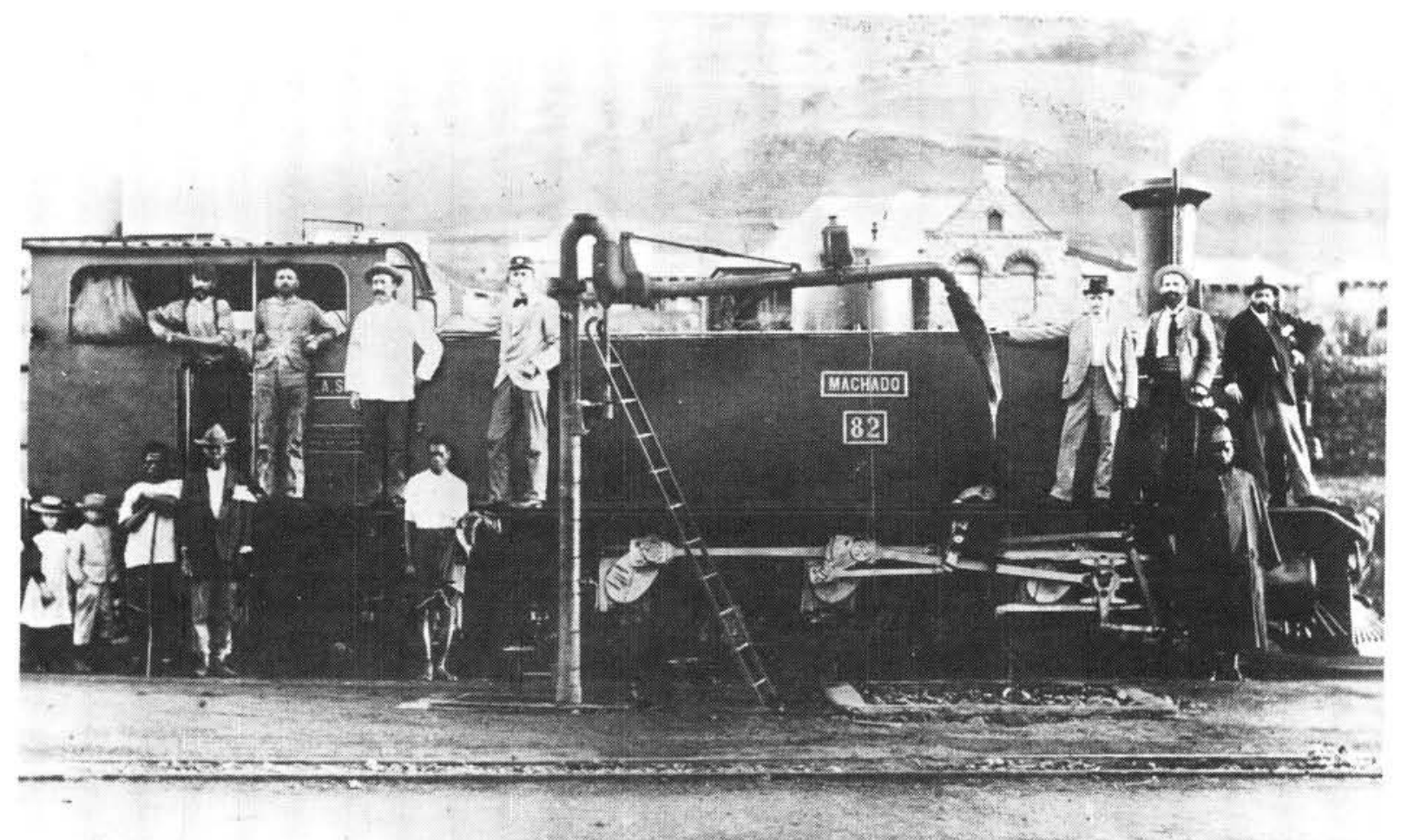

Watervalboven: Lokomotief Loods 1896

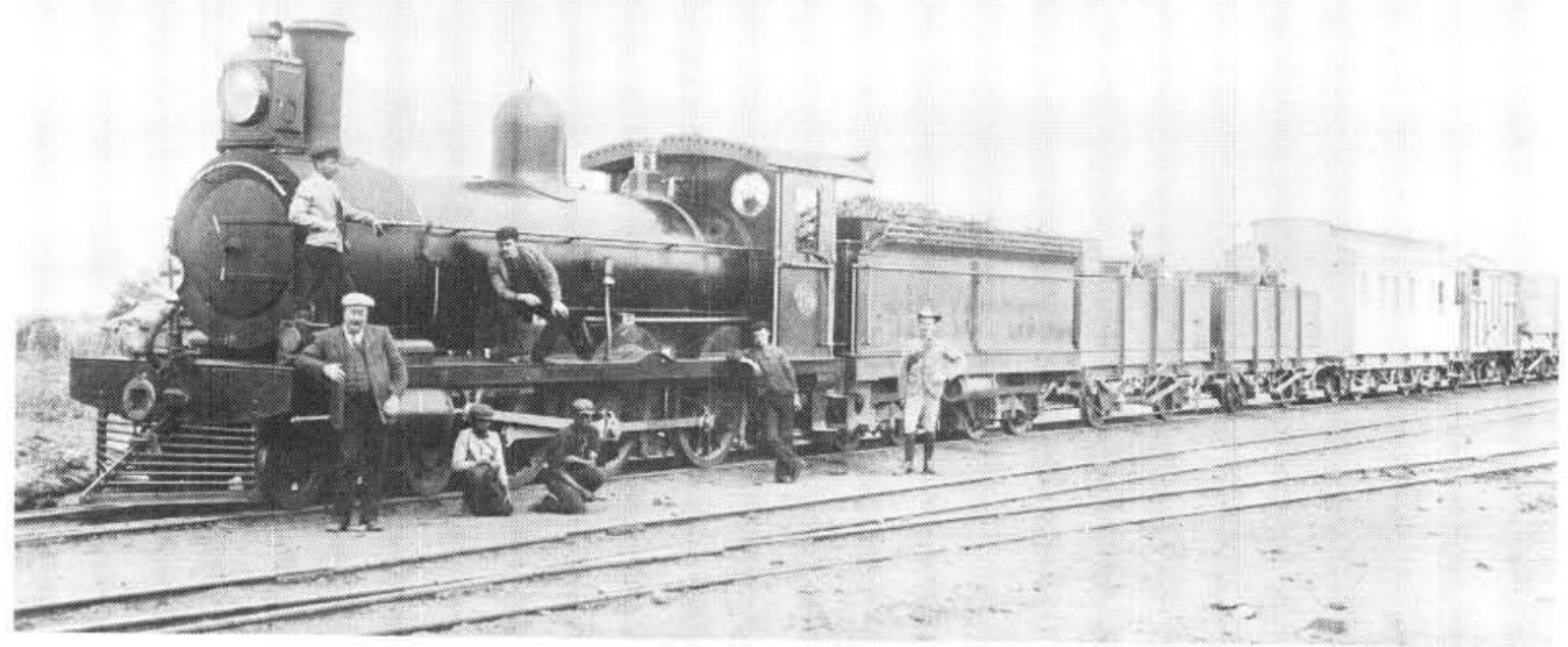

Rhodesië: Spoorwegtrajek tussen Mafeking en Bulawayo met CGR Idas 6 lokomotief 
The tactics used by these small groups consisted of destroying railway lines and bridges with an apparatus consisting of a Martini Henry rifle, with a sawn off barrel and butt. A live rifle round was converted to a blank by removing the bullet from the cartridge. The Martini Henry was then loaded with this "blank" cartridge which was then placed next to the dynamite percussion cap with the rifle barrel facing the cap and the trigger facing upwards, in such a manner that the locomotive's weight would trigger off the rifle and dynamite with resultant consequences. The "mine" would be placed underneath a joint connecting two rails, with the rail resting on top of the trigger. The rail being most flexible at this point, it would then be camouflaged with the same gravel taken from the same dugout. This all would be done at a long stretch of rail when the train would be travelling at speed.

Extract from: 'Met Genl. De Wet op Kommando' by Izak J.C. de Wet. Compiled by S/Lt. J.D. Bredenkamp of the Military Information Bureau.

\section{Note}

All photographs supplied by the Publicity and Travel Department of the South African Railways. 